\title{
Tekstur Yoghurt Susu Kambing dengan Perbedaan Jenis Starter dan Lama Fermentasi
}

\section{Texture of Goat Milk Yoghurt with Different Types of Starters and Length of Fermentation}

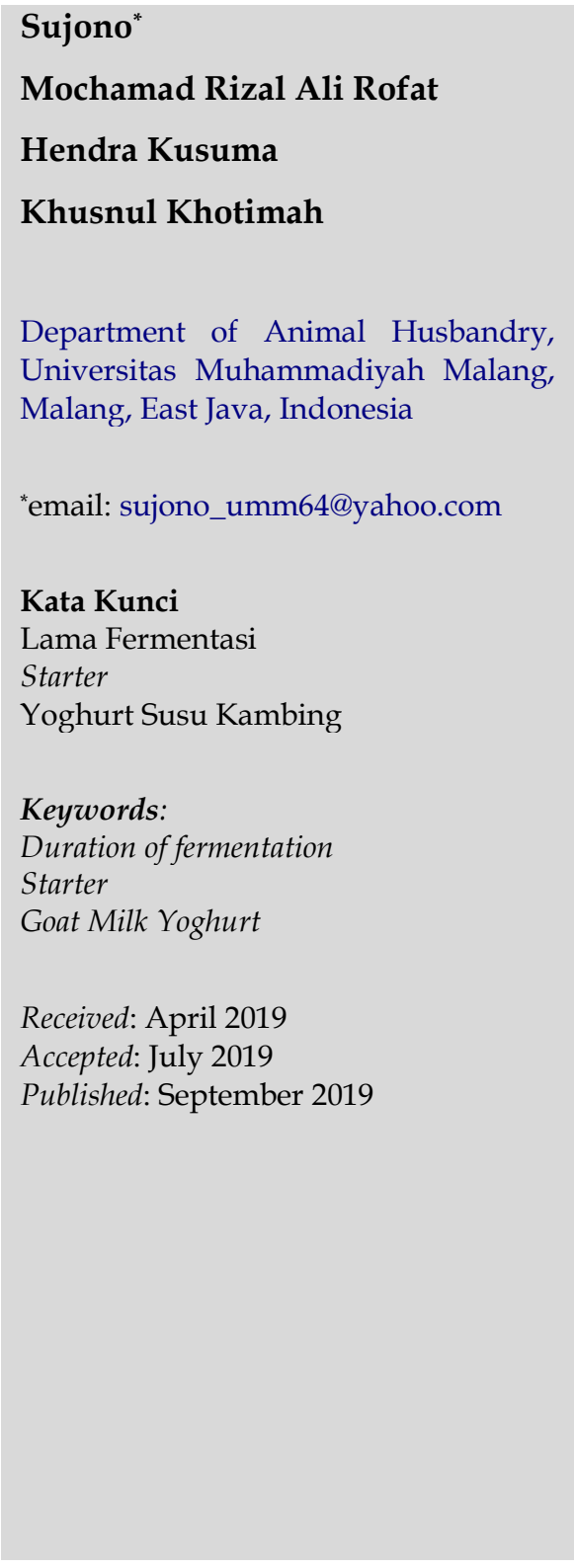

\begin{abstract}
Abstrak
Salah satu produk Program Pengembangan Usaha Produk Intelektual Kampus (PPUPIK) adalah yoghurt susu kambing, yoghurt sendiri merupakan minuman yang terbuat dari hasil fermentasi susu oleh bakteri asam laktat yang dilakukan secara terkontrol. Tekstur yoghurt sangat menentukan selera konsumen, untuk itu perlu dilakukan kajian tekstur yoghurt dengan jenis starter dan lama fermentasi yang berbeda. Hal ini agar diperoleh yoghurt dengan kualitas gizi maksimal dan tekstur kental lembut untuk memenuhi selera konsumen. Proses pembuatan yoghurt dengan lama fermentasi $(6,12,18$ dan 24$)$ jam dengan suhu $37^{\circ} \mathrm{C}$ dan jenis bakteri starter (Streptococcus thermophilus, Lactobacillus bulgaricus, dan kombinasi), sehingga terdapat 12 perlakuan dan di ulang sebanyak 3 kali. Parameter yang diamati oleh panelis adalah tekstur. Analisis tekstur yoghurt dianalisis de Garmo untuk mengetahui perlakuan yang paling sesuai dan banyak diminati panelis. Hasil uji de Garmo yang banyak disukai panelis yaitu fermentasi 24 jam menggunakan bakteri L. bulgaricus dengan nilai produk tekstur tertinggi 2,10 (kental khas yoghurt).
\end{abstract}

\begin{abstract}
One of the products of the Campus Intellectual Product Business Development Program (PPUPIK) is goat milk yoghurt, yoghurt itself is a drink made from fermented milk by lactic acid bacteria which is controlled. Yoghurt texture determines the tastes of consumers. Therefore it is necessary to study the texture of yoghurt with different types of starters and length of fermentation. This is to obtain yoghurt with maximum nutritional quality and a soft, thick texture to meet consumer tastes. The process of making yoghurt with fermentation time $\left(6,12,18\right.$ and 24) hours with $37^{\circ} \mathrm{C}$ temperature and the type of starter bacteria (Streptococcus thermophilus, Lactobacillus bulgaricus, and combinations), so that there were 12 treatments and repeated three times. The parameters observed by panellists are texture. The texture analysis of yoghurt was analyzed by de Garmo to find out the most appropriate treatment and much interest among panellists. Panellists favoured the de Garmo test results for 24-hour fermentation using the L. bulgaricus bacteria with the highest texture product value of 2.10 (regular thick yoghurt).
\end{abstract}

(c) 2019 Authors. Published by Institute for Research and Community Services Universitas Muhammadiyah Palangkaraya. This is Open Access article under the CC-BY-SA License (http://creativecommons.org/licenses/by-sa/4.0/). DOI: https://doi.org/10.33084/pengabdianmu.v4i2.687.

\section{PENDAHULUAN}

Yoghurt merupakan minuman berkualitas yang mengandung protein, fosfor, kalsium, magnesium, dan kalori. Yoghurt dikategorikan sebagai minuman multifungsional karena dapat mengatasi berbagai penyakit serta meningkatkan kebugaran dan daya tahan tubuh. Yoghurt memiliki nilai gizi yang lebih baik dari pada susu segar karena bakteri asam laktat mampu menguraikan protein susu menjadi bagian-bagian yang 
lebih sederhana sehingga mudah dicerna. Sementara itu, kandungan lemak dalam yoghurt lebih rendah. Yoghurt juga mengandung aneka zat gizi yang diperlukan tubuh seperti asam folat, asam nikotinat, asam pantotenat, biotin, vitamin B6, dan B12 (Salarkia et al., 2013; Kaleka \& Haryadi, 2013).

Pemanfaatan yoghurt dengan bahan baku susu sapi sudah sangat umum diketahui, sementara pemanfaatan yoghurt dengan bahan baku susu kambing belum banyak diketahui dampak terhadap kesehatan (Susanti \& Hidayat, 2016). Susu kambing dipilih karena memiliki kandungan laktosa yang rendah dan tidak mengandung senyawa beta-lactoglobulin sehingga tidak menimbulkan alergi. Selain itu susu kambing memiliki kandungan protein lebih tinggi dari susu sapi, sehingga sangat baik untuk pertumbuhan dan pembentukan jaringan tubuh (Paz et al., 2014).

Susu kambing banyak digunakan sebagai beberapa alternatif pengobatan atau terapi berbagai penyakit. Studi terbaru menunjukkan bahwa konsumsi makanan yang mengandung probiotik Streptococcus thermophilus dan Lactobacillus bulgaricus mampu mencegah atau mengurangi morbiditas dari lebih rendah infeksi saluran pernafasan dan infeksi enterik (Ahanchian et al., 2016). Probiotik Yoghurt mengandung mikroba ini dilaporkan memiliki efek menguntungkan pada metabolism (Guerra, 2012). Bakteri ini memiliki banyak keunggulan dalam proses pembuatan yoghurt yaitu sebagai biokatalis proses fermentasi, dapat memproduksi asam laktat, asetaldehida serta diasetil dari laktosa susu dan berperan penting dalam menjaga mikroflora usus karena mampu menciptakan keadaan asam yang menghambat pertumbuhan bakteri lain (Pu et al., 2017).

Penambahan bakteri starter membuat proses pembuatan yoghurt akan lebih singkat dan mengasilkan produk yoghurt yang berkualitas. Pembentukan kualitas tekstur yoghurt tergantung pada banyak faktor antara lain jenis bakteri starter, temperatur proses fermentasi, komposisi susu, proses pembuatan dan masa penyimpanan (Gianti \& Evanuarini, 2011). Sifat fisik merupakan salah satu kriteria penentuan kualitas susu fermentasi,sifat tersebut terbentuk akibat adanya asam laktat yang dihasilkan oleh bakteri asam laktat yang mempengaruhi muatan elektrostatik kasein, sehingga terbentuk interaksi protein-protein karena menurunnya daya tolak elektrostatik dan terjadi pengikatan kalsium ke kasein sehingga memacu ikatan hidrofobik antara kasein (Manab, 2008). Tekstur yoghurt terbentuk oleh agregasi misel kasein oleh asam dan adanya interaksi antara misel kasein sehingga terbentuk gel yang kuat dan halus. Kekuatan gel kasein yang terbentuk ditentukan oleh kekuatan ikatan antara misel kasein dengan misel kasein yang kekuatan ikatannya dipengaruhi oleh $\mathrm{pH}$, konsentrasi kalsium dan suhu (Desouky \& El-Gendy, 2017; Pradipta \& Paramita, 2017).

Kegiatan Pengabdian kepada Masyarakat ini dilakuakan dengan tujuan untuk mengetahui pengaruh perbedaan jenis bakteri starter yang digunakan serta lama proses fermentasi terhadap tekstur dari yoghurt susu kambing yang dihasilkan. Oleh karena itu telah dilakukan uji fisik tekstur yoghurt susu kambing pada Program Pengembangan Usaha Produk Intelektual Kampus (PUPPIK) pada panelis yang terdiri dari beberapa orang mahasiswa, karena yoghurt susu kambing ini merupakan salah satu produk PUPPIK. Hal ini dimaksudkan untuk mendapatkan rasa yang maksimal sehingga disukai konsumen yang sebagian besar adalah mahasiswa.

\section{METODOLOGI}

Kegiatan ini merupakan hasil dari program Pengabdian kepada Masyarakat PUPPIK Tahun ke-2. Kegiatan PUPPIK dilakukan di laboratorium Jurusan Peternakan Universitas Muhammadiyah Malang untuk mengamati 
lama proses fermentasi yoghurt susu kambing dengan lama fermentasi dan jenis penambahan bakteri starter yang berbeda untuk mendapatkan rasa yoghurt yang paling disukai. Susu yang digunakan susu kambing dan bakteri starter yang digunakan adalah $S$. thermophilus, $L$. bulgaricus, serta campuran keduanya dengan Perbandingan $1: 1$. Proses fermentasi dilakukan dalam inkubator dengan suhu $37^{\circ} \mathrm{C}$, kemudian dilakukan pengujian $\mathrm{pH}$, rasa dan tekstur dari yoghurt susu kambing.

Perlakuan yang digunakan pada penelitian ini sebanyak 12 kelompok perlakuan, dengan penjelasan untuk setiap perlakuan sebagai berikut:

1. Faktor 1: Variasi lama waktu fermentasi (W)
a. $W_{1}$ : Lama waktu fermentasi 6 jam
b. $W_{2}$ : Lama waktu fermentasi $12 \mathrm{jam}$
c. $\mathrm{W}_{3}$ : Lama waktu fermentasi $18 \mathrm{jam}$
d. $W_{4}$ : Lama waktu fermentasi 24 jam

2. Faktor 2: Variasi bakteri starter ( $\mathrm{S}$ )
a. S: Bakteri starter S. thermophilus
b. $S_{2}$ : Bakteri starter L. bulgaricus
c. $S_{3}$ : Bakteri starter kombinasi

Berdasarkan faktor-faktor tersebut, dibuat satu kombinasi antara kedua faktor tersebut, sehingga diperoleh $4 \times 3=12$ kombinasi perlakuan dengan rincian seperti terlihat pada Tabel I.

Tabel I. Rancangan Perlakuan Penelitian

\begin{tabular}{c|cccc}
\hline Faktor & $\mathbf{W}_{\mathbf{1}}$ & $\mathbf{W}_{\mathbf{2}}$ & $\mathbf{W}_{3}$ & $\mathbf{W}_{\mathbf{4}}$ \\
\hline $\mathbf{S}_{\mathbf{1}}$ & $\mathrm{W}_{1} \mathrm{~S}_{1}$ & $\mathrm{~W}_{2} \mathrm{~S}_{1}$ & $\mathrm{~W}_{3} \mathrm{~S}_{1}$ & $\mathrm{~W}_{4} \mathrm{~S}_{1}$ \\
$\mathbf{S}_{\mathbf{2}}$ & $\mathrm{W}_{1} \mathrm{~S}_{2}$ & $\mathrm{~W}_{2} \mathrm{~S}_{2}$ & $\mathrm{~W}_{3} \mathrm{~S}_{2}$ & $\mathrm{~W}_{4} \mathrm{~S}_{2}$ \\
$\mathbf{S}_{3}$ & $\mathrm{~W}_{1} \mathrm{~S}_{3}$ & $\mathrm{~W}_{2} \mathrm{~S}_{3}$ & $\mathrm{~W}_{3} \mathrm{~S}_{3}$ & $\mathrm{~W}_{4} \mathrm{~S}_{3}$ \\
\hline
\end{tabular}

Untuk teknik pembuatan yoghurt dari berbagai perlakuan tersebut disajikan pada Gambar 1 dalam bentuk skema.

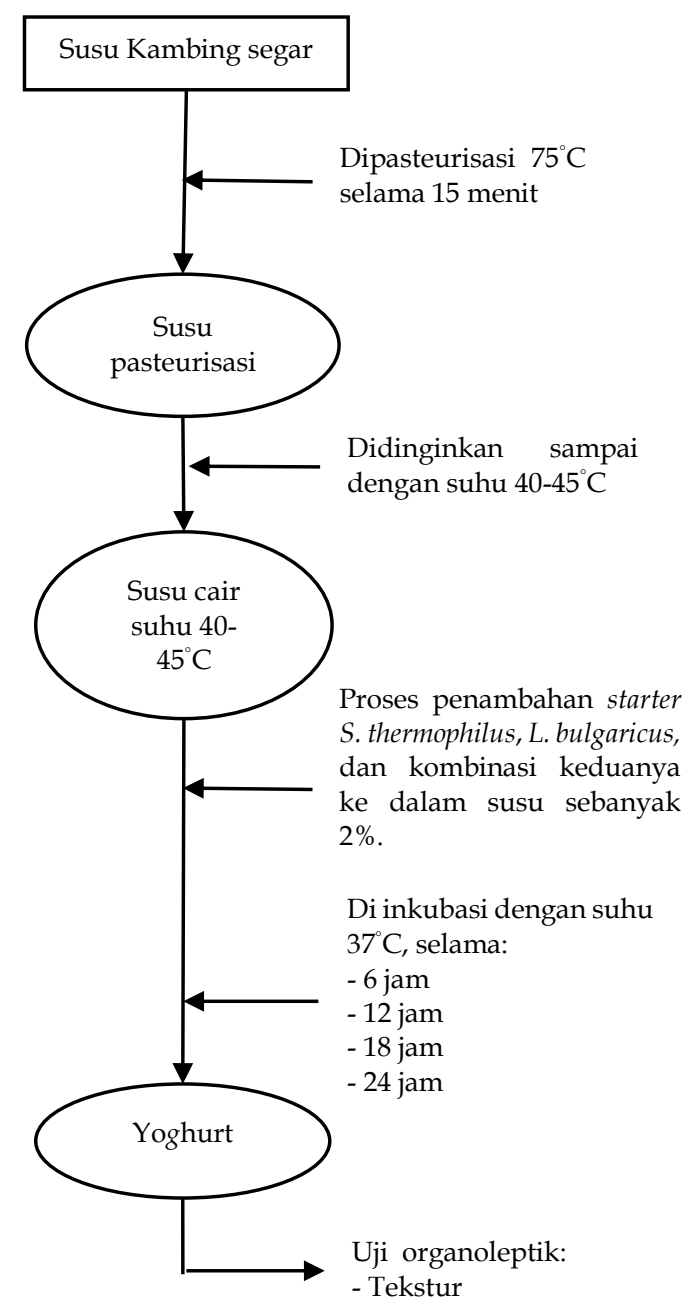

Gambar 1. Proses Pembuatan Yoghurt dengan Jenis Starter dan Lama Fermentasi yang Berbeda.

Hasil uji panelis dilakukan dengan metode de Garmo berdasarkan skala uji 1 = tidak suka; 2 = cukup suka; dan 3 = suka. Penentuan perlakuan yang paling baik diperoleh berdasarkan hasil dari analisis kedua metode tersebut.

\section{HASIL DAN PEMBAHASAN}

Konsumen akan memilih produk makanan atau minuman yang memiliki tekstur yang baik dan sesuai dengan standarisasi (Tarwendah, 2017). Tekstur yang dinilai panelis ialah tekstur yoghurt susu kambing dari seluruh sampel uji yoghurt susu kambing. Pengujian organoleptik diperlukan untuk mengetahui daya terima konsumen terhadap produk yoghurt (Rahayu \& 
Adriani, 2018). Berdasarkan hasil penilaian seluruh panelis didapatkan rata-rata nilai untuk tekstur yoghurt susu kambing. Hasil yang diperoleh menunjukkan bahwa rentang penilaian panelis terhadap tekstur yoghurt susu kambing yang dihasilkan tidak terdapat perbedaan yang signifikan. Formulasi yoghurt menggunakan starter $S$. thermophilus memiliki rerata penilaian tertinggi pada lama fermentasi 18 dan 24 jam yaitu sebesar 2,13, sedangkan rerata penilaian terendah adalah pada lama fermentasi 6 jam dengan nilai sebesar 2,08. Yoghurt dengan starter L. bulgaricus memiliki rerata penilaian tertinggi pada lama fermentasi 24 jam dengan nilai sebesar 2,47, sementara rerata penilaian terendah ditunjukkan pada lama fermentasi 6 jam yaitu sebesar 1,85. Yoghurt yang menggunakan starter kombinasi memiliki rerata penilaian tertinggi pada lama fermentasi 24 jam yaitu sebesar 2,27, sedangkan rerata penilaian terendah yaitu pada lama fermentasi 6 dan 12 jam yaitu sebesar 2,10. Hasil diagram batang rerata kesukaan panelis terhadap formula yoghurt susu kambing disajikan pada Gambar 2.

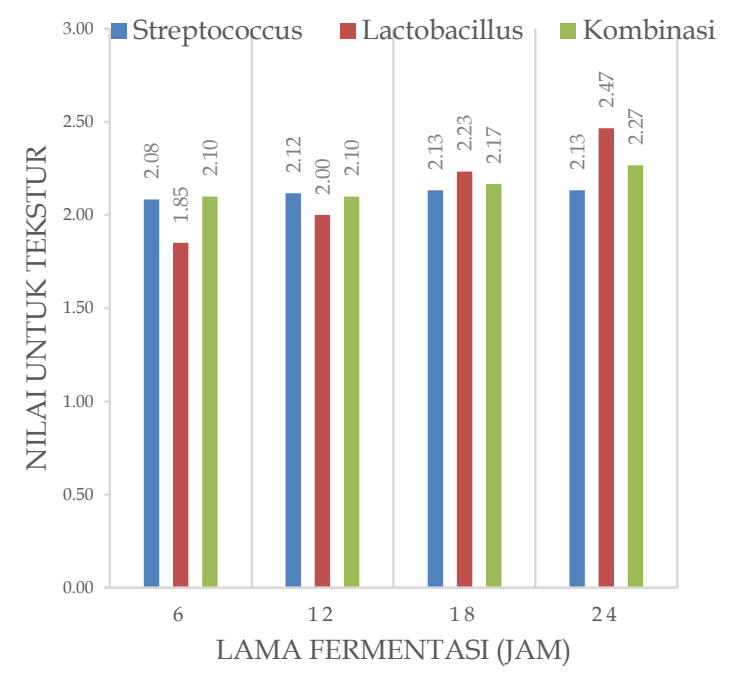

Gambar 2. Diagram Batang Rerata Kesukaan Panelis terhadap Tekstur Yoghurt Susu Kambing.

Data tersebut kemudian dianalisis lebih lanjut menggunakan metode de Garmo untuk mengetahui perlakuan yang terbaik dengan mempertimbangkan beberapa parameter seperti nilai efektivitas (NE), bobot nilai $(\mathrm{BN})$, serta nilai produk (NP) (De Garmo et al., 1984). Berdasarkan data hasil analisis diatas penentuan perlakuan yang paling sesuai dapat dilihat dari hasil nilai NP, dimana dapat dilihat bahwa perlakuan pada jenis starter apapun, dengan lama waktu perlakuan yang paling baik adalah $\mathrm{W}_{4} \mathrm{~S}_{2}$ dengan nilai NP sebesar 2,10. Semakin tinggi nilai NP maka akan semakin baik, disamping nilai NP yang paling tinggi, rerata pada perlakuan $W_{4} S_{2}$ juga yang paling tinggi apabila dibandingkan dengan perlakuan lainnya yaitu sebesar 2,47. Nilai tersebut dapat dikategorikan bahwa dari segi tekstur panelis cenderung lebih menyukai yoghurt hasil perlakuan $\mathrm{W}_{4} \mathrm{~S}_{2}$ bila dibandingan dengan yoghurt pada perlakuan yang lainnya, dengan penilaian (suka) kental khas yoghurt. Sehingga dapat dikatakan dengan menggunakan bakteri starter $L$. bulgaricus dan semakin lama waktu fermentasi (24 jam), maka akan menghasilkan yoghurt dengan tekstur paling banyak disukai oleh konsumen. Hasil analisis de Garmo disajikan pada Tabel II.

Tabel II. Hasil Perhitungan Analisis De Garmo Tekstur Yoghurt Susu Kambing

\begin{tabular}{|c|c|c|c|c|c|}
\hline Perlakuan & Rerata & Sorting & $\mathrm{NE}$ & $\mathbf{B N}$ & $\mathbf{N P}$ \\
\hline$\overline{W_{1} S_{1}}$ & 2,08 & 2,47 & 0,38 & 0,47 & 0,79 \\
\hline $\mathrm{W}_{2} \mathrm{~S}_{1}$ & 2,12 & 2,27 & 0,43 & 0,47 & 0,91 \\
\hline $\mathrm{W}_{3} \mathrm{~S}_{1}$ & 2,13 & 2,23 & 0,46 & 0,47 & 0,96 \\
\hline $\mathrm{W}_{4} \mathrm{~S}_{1}$ & 2,13 & 2,17 & 0,46 & 0,47 & 0,96 \\
\hline $\mathrm{W}_{1} \mathrm{~S}_{2}$ & 1,85 & 2,13 & 0,00 & 0,47 & 0,00 \\
\hline $\mathrm{W}_{2} \mathrm{~S}_{2}$ & 2,00 & 2,13 & 0,24 & 0,47 & 0,51 \\
\hline $\mathrm{W}_{3} \mathrm{~S}_{2}$ & 2,23 & 2,12 & 0,62 & 0,47 & 1,31 \\
\hline $\mathrm{W}_{4} \mathrm{~S}_{2}$ & 2,47 & 2,10 & 0,99 & 0,47 & 2,10 \\
\hline $\mathrm{W}_{1} \mathrm{~S}_{3}$ & 2,10 & 2,10 & 0,40 & 0,47 & 0,85 \\
\hline $\mathrm{W}_{2} \mathrm{~S}_{3}$ & 2,10 & 2,08 & 0,40 & 0,47 & 0,85 \\
\hline $\mathrm{W}_{3} \mathrm{~S}_{3}$ & 2,17 & 2,00 & 0,51 & 0,47 & 1,08 \\
\hline $\mathrm{W}_{4} \mathrm{~S}_{3}$ & 2,27 & 1,85 & 0,67 & 0,47 & 1,42 \\
\hline $\begin{array}{c}\text { Nilai } \\
\text { Terbaik }\end{array}$ & \multicolumn{5}{|c|}{2,47} \\
\hline $\begin{array}{c}\text { Nilai } \\
\text { Terburuk }\end{array}$ & \multicolumn{5}{|c|}{1,85} \\
\hline Selisih & \multicolumn{5}{|c|}{0,62} \\
\hline
\end{tabular}

Keterangan: NE: Nilai Efektivitas; BN: Bobot Nilai; NP: Nilai Produk (Hasil) 
Menurut Rosiani et al. (2015), rasa yang dihasilkan suatu makanan atau minuman dipengaruhi oleh konsentrasi dan tekstur bahan tersebut. Keterangan tersebut diperkuat oleh Rahayu dan Andriani (2018) yang menyatakan bahwa faktor yang mempengaruhi kualitas yoghurt antara lain substrat, jenis starter, konsentrasi starter, suhu dan waktu inkubasi. Produk fermentasi yang tidak berbahan dasar susu mudah sekali mengalami sineresis, oleh karena itu dibutuhkan bahan yang menghasilkan yoghurt dengan tekstur yang stabil

\section{KESIMPULAN}

Berdasarkan pengamatan diperoleh hasil bahwa berdasarkan analisis hasil uji de Garmo terhadap tekstur, kombinasi lama fermentasi, serta jenis bakteri starter, kelompok yang paling banyak disukai panelis yaitu starter L. bulgaricus dengan lama fermentasi 24 jam dengan nilai rasa $=2,10$ (perlakuan $\mathrm{W}_{4} \mathrm{~S}_{2}$ ). Dengan demikian, untuk mendapatkan tekstur yoghurt yang disukai konsumen sebaiknya mengggunakan starter $L$. bulgaricus dengan lama fermentasi 24 jam karena dihasilkan rasa dan tekstur terbaik.

\section{REFERENSI}

Ahanchian, H., Jafari, S.A., Ansari, E., Ganji, T., Kiani, M.A., Khalesi, M., Momen, T., Kianifar, H. 2016. A multi-strain Synbiotic may reduce viral respiratory infections in asthmatic children: a randomized controlled trial. Electronic Physician. 8(9):2833-2839. https://dx.doi.org/10.19082/2833

De Garmo, E.D., Sullivan, W.G., Canada, J.R. 1984. Engineering Economy. New York: Macmillan Publishing Company.

Desouky, M.M., El-Gendy, M.H. 2017. Physicochemical Characteristics of Functional Goats' Milk Yogurt as Affected by some Milk Heat Treatments. International Journal of Dairy
Science.

12(1):12-27.

http://dx.doi.org/10.3923/ijds.2017.12.27

Gianti, I., Evanuarini, H. 2011. Pengaruh Penambahan Gula dan Lama Penyimpanan Terhadap Kualitas Fisik Susu Fermentasi. Jurnal Ilmu dan Teknologi Hasil Ternak. 6(1):28-33.

Guerra, N.P. 2012. A Review on Some Chemical Engineering and Microbiological Aspects Considered in the Production of Highly Concentrated Probiotic Cultures and Bacteriocins by Lactococci and Lactobacilli. ISRN Chemical Engineering. 2012:836381. https://doi.org/10.5402/2012/836381

Kaleka, N., Haryadi, N.K. 2013. Kambing Perah. Solo: Arcita.

Manab, A. 2012. Kajian Sifat Fisik Yogurt selama Penyimpanan pada Suhu $4^{\circ} \mathrm{C}$. Jurnal Ilmu dan Teknologi Hasil Ternak. 3(1):52-58.

Paz, N.F., de Oliveira, E.G., de Kairuz, M.S.N., Ramon, A.N. 2014. Characterization of goat milk and potentially symbiotic non-fat yogurt. Food Science and Technology. 34(3):629-635. http://dx.doi.org/10.1590/1678-457x.6409

Pradipta, T., Paramita, V. 2017. Studi Pengaruh Penambahan Penambahan Berbagai Starter Pada Susu Kacang Fermentasi Terhadap Sifat Fisik Susu. METANA. 13(2):49-54. https://doi.org/10.14710/metana.v13i2.1801 3

Pu, F., Guo, Y., Li, M., Zhu, H., Wang, S., Shen, X., He, M., Huang, C., He, F. 2017. Yogurt supplemented with probiotics can protect the healthy elderly from respiratory infections: A randomized controlled open-label trial. Clinical Interventions in Aging. 12:1223-1231. https://dx.doi.org/10.2147/CIA.S141518

Rahayu, P.P., Andriani, R.D. 2018. Mutu Organoleptik dan Total Bakteri Asam Laktat Yogurt Sari Jagung dengan Penambahan Susu Skim dan Karagenan. Jurnal Ilmu dan Teknologi Hasil Ternak. 3(1):38-45. https://doi.org/10.21776/ub.jitek.2018.013.01 .4

Rosiani, N, Basito, Widowati, E. 2015. Kajian Karakteristik Sensoris Fisik dan Kimia Kerupuk Fortifikasi Daging Lidah Buaya (Aloe Vera) dengan Metode Pemanggangan 
Menggunakan Microwave. Jurnal Teknologi Hasil Pertanian. 8(2):84-98. https://doi.org/10.20961/jthp.v0i0.12896

Salarkia, N., Ghadamli, L., Zaeri, F., Rad, L.S. 2013. Effects of probiotic yogurt on performance, respiratory and digestive systems of young adult female endurance swimmers: a randomized controlled trial. Medical Journal of The Islamic Republic of Iran. 27(3):141.

Susanti, R., Hidayat, E. 2016. Profil Protein Susu dan Produk Olahannya. Jurnal MIPA. 39(2):98-106.

Tarwendah, I.P. 2017. Jurnal Review: Studi Komparasi Atribut Sensoris dan Kesadaran Merek Produk Pangan. Jurnal Pangan dan Agroindustri. 5(2):66-73. 